\title{
Association between Human Ecological Factors and Visual Spatial Intelligence of Young Adolescents
}

\author{
Sumit Sheoran*, Sudha Chhikara and Sheela Sangwan
}

\author{
Department of Human Development and Family Studies , I.C. College of Home Science, \\ CCSHAU, Hisar, Haryana- 125004, India
}

*Corresponding author

\section{A B S T R A C T}

\begin{tabular}{|l|}
\hline Key w or d s \\
Visual spatial \\
intelligence, \\
Parental \\
involvement and \\
other human \\
ecological factors
\end{tabular}

Spatial (picture) Intelligence adheres particularly to the capacity to process information through visualization. Children who favor a spatial intelligence lean to discover through visual aids and images and individuals with strong spatial intelligence will gravitate towards artistic and highly visual forms of learning. Visual artists and interior designers illustrate creative spatial abilities and a flourishing architect will necessitate both the creative abilities as well as technical achievement. Ecological Systems Theory proposed by Urie Bronfenbrenner emphasized that there are five layers arranged from the closest to the individual to the farthest: the microsystem, mesosystem, exosystem, macrosystem and chronosystem. These all systems directly or indirectly influence the individual growth and development. Hence, the association of these variables was studied along with Multiple Intelligence of the young adolescents. For this, 200 respondents in the age group of 12-14 years from both urban and rural area of Mahendergarh district of Haryana state were selected. Cultural setting and membership of any club/organization by the respondents' and their parents were significantly associated with visual spatial intelligence. Neither relationship nor interaction of the respondents with the neighbors had any significant association with visual spatial intelligence. It is clear from the research that the other variables had no significant association with visual spatial intelligences of the respondents.

\section{Introduction}

Spatial intelligence is one of Howard Gardner's nine multiple intelligences. The word spatial is derived from the Latin "spatium" meaning "occupying space." Logically, it may be concluded that this intelligence includes how well a student may process stimulus that is offered visually in one or more dimensions. This intelligence includes the ability to envisage objects, transform and manipulate them. Spatial intelligence is a foundation upon which many of the other eight intelligences depends and interact. Engineers, innovators, architects, scientists and artists are among those who have dominant spatial intelligence famous artists such as Leonardo da Vinci and Pablo Picasso. A widely used Intelligence Quotient test can help educationalists determine what students to acknowledge-mainly measures quantitative and verbal/ linguistic abilities. 
Yet, neglecting visual spatial abilities of children could have widespread consequences in education. Students with relatively strong spatial abilities tend to gravitate towards scientific and technical fields such as the engineering, physical sciences, mathematics, and computer science.

Persons with spatial intelligence are capable to think in three-dimensions. Such people excel by mentally manipulating objects, like drawing or art, akin to design or build things and enjoy puzzles.

Individuals can enhance and strengthen their spatial intelligence by performing various activities such as: practicing visualization techniques, including artwork, photography or drawing in classes, solving puzzles, using maps and visual aids. Spatial intelligence is a skill few are born with, yet it is often the most neglected. Planning daily routine lesson plans as per visual spatial intelligence may be the key to help students be successful in all areas of life.

Agarwal and Suraksha (2017) revealed that male and female students do not differ with reference to Multiple Intelligences. Female students possess more linguistic, spatial, musical, interpersonal, intrapersonal and existential intelligence than male students.

Thangapappa et al., (2014) elucidated that religion, caste, and family status, annual incomes of parents', parents' qualification and occupation have no remarkable significant relationship with Multiple Intelligences.

Beceren (2010) found a relationship between children's intelligence types and their parents' educational level and socio-economic status and also concluded that parent's educational level and their socio-economic status directly affects children's intelligences.
To assess the association of human ecological variables with visual spatial intelligence of the young adolescents.

\section{Materials and Methods}

The present study was planned in Haryana state. Out of total backward districts of Haryana state one was selected randomly. Multi stage sampling procedure was followed to have the representative sample. For rural sample, one block was elected at random from the selected district. From elected block one village having Government High/Senior Secondary Schools and Private High/Senior Secondary Schools was taken purposively. Similarly, for urban sample, one Government High/Senior Secondary Schools and Private High/Senior Secondary School was taken randomly from the selected city.

\section{Selection of respondents}

A list of girl students in the age group of 1214 years was obtained from both the selected schools of each area. A sample of 200 young adolescent girls was taken randomly from the list of both selected schools of rural and urban areas. Out of 200 adolescent girls, 100 from urban and 100 from rural areas were selected randomly. This sample of 100 adolescent girls constituted of 50 girls each from Government and Private Schools.

\section{Instrument of the study}

The primary data was collected by using questionnaire-cum-interview schedule developed by Kaur (2006). The tool consisted of nine subscales namely, bodily kinesthetic, interpersonal, intrapersonal, linguistic, logical mathematical, visual spatial, naturalistic and existential intelligences. This tool was selected as it is reliable, its retest reliability coefficients 
for nine components were in the range of 0.63 to 0.86 and for interobserver reliability coefficients it was ranging from 0.61 to 0.90 . Tool is also valid as its content validity ratio was ranging from 0.2 to 0.8 and its cross validity was ranging from 0.02 to 3.49 . Scoring pattern used for visual spatial intelligences is given below:

\begin{tabular}{|c|c|}
\hline Visual spatial Intelligence & Code/Scoring Pattern \\
\hline Above average (18 and above) & 1 \\
\hline Average (13-17) & 2 \\
\hline $\begin{array}{c}\text { Below average (12 and } \\
\text { below) }\end{array}$ & 3 \\
\hline
\end{tabular}

\section{Analysis of the data}

Chi square test of independence was used to calculate the degree of association between dependent and independent variables.

\section{Results and Discussion}

Results in table 1 revealed that none of the human ecological variables (parental occupation and frequency of visit to relatives/friends) were found to be significantly associated with visual spatial intelligence of the young adolescent girls.

Table 2 showed the association between human ecological variables and visual spatial intelligence. Caste (12.78) was observed to be significantly associated with visual spatial intelligence. It is clear from the results that the availability of newspaper at home had significant association with visual spatial intelligence (6.66).

Table.1 Association of human ecological variables with visual spatial intelligence $\quad \mathrm{N}=200$

\begin{tabular}{|c|c|c|c|c|c|}
\hline \multirow[t]{2}{*}{$\begin{array}{l}\text { Sr. } \\
\text { No. }\end{array}$} & \multirow[t]{2}{*}{ Variables } & $\begin{array}{c}\text { Above } \\
\text { Average }\end{array}$ & Average & $\begin{array}{c}\text { Below } \\
\text { Average }\end{array}$ & \multirow[t]{2}{*}{$\begin{array}{c}\text { Chi square } \\
\text { value }\end{array}$} \\
\hline & & $\mathbf{F}(\%)$ & $\mathbf{F}(\%)$ & $\mathbf{F}(\%)$ & \\
\hline \multirow[t]{4}{*}{1.} & \multicolumn{5}{|c|}{ Mothers' occupation } \\
\hline & Service & $50(25.0)$ & $39(19.5)$ & $8(4.0)$ & \multirow{3}{*}{8.55} \\
\hline & Business & $20(10.0)$ & $3(1.5)$ & - & \\
\hline & Homemaker & $41(20.5)$ & $36(18.0)$ & $3(1.5)$ & \\
\hline \multirow[t]{4}{*}{2.} & \multicolumn{5}{|c|}{ Fathers' occupation } \\
\hline & Service & $68(34.0)$ & $42(21.0)$ & $4(2.0)$ & \multirow{3}{*}{7.66} \\
\hline & Business & $30(15.0)$ & $24(12.0)$ & $7(3.5)$ & \\
\hline & Farming & $13(6.5)$ & $12(6.0)$ & - & \\
\hline \multirow[t]{4}{*}{3.} & Frequency of vis & es/friends & & & \\
\hline & Frequently & $10(5.0)$ & $40(20.0)$ & $30(15.0)$ & \multirow{3}{*}{3.89} \\
\hline & Occasionally & $12(6.0)$ & $48(24.0)$ & $30(15.0)$ & \\
\hline & Rarely & $9(4.5)$ & $13(6.5)$ & $8(4.0)$ & \\
\hline
\end{tabular}

*Significant at 0.05

Note: Figures in the parentheses indicate percentage 
Table.2 Association of human ecological variables with visual spatial intelligence

\begin{tabular}{|c|c|c|c|c|c|}
\hline $\begin{array}{l}\text { Sr. } \\
\text { No. }\end{array}$ & Variables & $\begin{array}{l}\text { Above } \\
\text { Average } \\
\text { F }(\%)\end{array}$ & Average & $\begin{array}{l}\text { Below } \\
\text { Average } \\
\text { F }(\%)\end{array}$ & $\begin{array}{l}\text { Chi } \\
\text { square } \\
\text { value }\end{array}$ \\
\hline \multirow[t]{4}{*}{1.} & \multicolumn{5}{|l|}{ Caste } \\
\hline & General & $10(5.0)$ & $9(4.5)$ & - & \multirow{3}{*}{$12.78^{*}$} \\
\hline & Scheduled Caste & $60(30.0)$ & $34(17.0)$ & $2(1.0)$ & \\
\hline & Backward Class & $41(20.5)$ & $34(17.0)$ & $10(5.0)$ & \\
\hline \multirow[t]{3}{*}{2.} & \multicolumn{5}{|c|}{ Exposure to mass media } \\
\hline & Yes & $76(38.0)$ & $52(26.0)$ & $7(3.5)$ & \multirow[t]{2}{*}{0.14} \\
\hline & No & $35(17.5)$ & $26(13.0)$ & $4(2.0)$ & \\
\hline \multirow[t]{4}{*}{3.} & \multicolumn{5}{|l|}{ Discipline by parents } \\
\hline & Authoritative & $45(22.5)$ & $29(14.5)$ & $2(1.0)$ & \multirow{3}{*}{2.41} \\
\hline & Permissive & $65(32.5)$ & $48(24.0)$ & $9(4.5)$ & \\
\hline & Authoritarian & $1(0.5)$ & $1(0.5)$ & - & \\
\hline \multirow[t]{4}{*}{4.} & \multicolumn{5}{|c|}{ Type of people living in nearby area } \\
\hline & High class & $5(2.5)$ & $10(5.0)$ & $5(2.5)$ & \multirow{3}{*}{1.07} \\
\hline & Middle class & $30(15.0)$ & $70(35.0)$ & $40(20.0)$ & \\
\hline & Low class & $8(4.0)$ & $17(8.5)$ & $15(7.5)$ & \\
\hline \multirow[t]{3}{*}{5.} & \multicolumn{5}{|c|}{ Availability of newspaper at home } \\
\hline & Yes & $59(29.0)$ & $49(24.5)$ & $10(5.0)$ & \multirow[t]{2}{*}{$6.66^{*}$} \\
\hline & No & $52(26.0)$ & $29(14.5)$ & $1(0.5)$ & \\
\hline
\end{tabular}

*Significant at 0.05

Note: Figures in the parentheses indicate percentage

The conclusion and recommendation of the study are as follows:

It was discovered that none of the human ecological variables i.e., parental occupation and frequency of visit to relatives/friends were found to be significantly associated with visual spatial intelligence of the young adolescent girls (Table 1). In 2014, similar results were also observed by Thangapappa, et.al. Along with that results regarding the association between human ecological variables and visual spatial intelligence presented that caste and availability of newspaper was observed to be significantly associated with visual spatial intelligence (Table 2). Intelligence plays a keen role in life and leads to the personal, social and harmonious development of the personality of an individual (Kandeel, 2016). Hence, parents and teachers should take steps to enhance the development of visual spatial intelligence domain of the children. To boost visual spatial intelligence among students, parents and teachers should provide opportunities to promote reasoning, engage them more in visual imageries, employ them in designing and decorating and effective teaching strategies must be used which assist the development of child. Though these are the suggestions to enhance visual-spatial intelligence among students, it is not empirically proven. Hence such above stated studies can be undertaken in these areas. The 
teachers must help the students to develop visual-spatial intelligence by exposing them to a variety of ways of learning, to better individualized for their interests and needs, and to use teaching strategies that make learning more efficient, successful and enjoyable for the children. Meaningful learning experiences can also be fostered by using multiple teaching tools and strategies along with that building positive and supportive relationship with the children is also of equal importance.

\section{References}

Agarwal S., and Suraksha (2017) A Comparative Study of Multiple Intelligence Among Male and Female Students of Class XI. International Journal of Advanced Research in
Education \& Technology (IJARET). Vol. 4 (1).

Beceren, B.O., (2010). Determining Multiple Intelligences Pre-school Children (4-6 age) in Learning Process. ProcediaSocial and Behavioral Sciences. Vol. 2 (2), pp: 2473-2480.

Kandeel, R., A., (2016) Multiple Intelligences Patterns among Students at King Saud University and Its Relationship with Mathematics' Achievement. Journal of Education and Learning. Vol. 5(3), pp: 94-106.

Thangpappa, R., Thamocharan, V., and Kanakaraj., T., (2014). Influence of the Multiple intelligence on Achievement of Undergraduate Zoology Students. Indian Journal of Applied Research. Vol. 2, pp: 15-17.

\section{How to cite this article:}

Sumit Sheoran, Sudha Chhikara and Sheela Sangwan. 2018. Association between Human Ecological Factors and Visual Spatial Intelligence of Young Adolescents. Int.J.Curr.Microbiol.App.Sci. 7(12): 1743-1747. doi: https://doi.org/10.20546/ijcmas.2018.712.202 